\title{
Radical-Scavenging Activity of Orsellinates
}

\author{
Thiago Inácio Barros Lopes, Roberta Gomes Coelho, Nídia Cristiane YoshidA, and \\ Neli Kika HondA* \\ Departamento de Química, Universidade Federal de Mato Grosso do Sul; P. O. Box 549, 79070-900, Campo Grande, \\ Mato Grosso do Sul, Brazil. Received May 17, 2008; accepted July 26, 2008; published online August 21, 2008
}

\begin{abstract}
Lichens are an important source of phenolic compounds and have been intensively investigated for their biological and pharmacological activities. Lecanoric acid (1), a lichen depside, was isolated from a Parmotrema tinctorum specimen and treated with alcohols to produce orsellinic acid (2) and orsellinates (3) to (9) $(2,4-d i h y-$ droxy-6-n-methyl benzoates). Free radical scavenging activity of methyl (3), ethyl (4), n-propyl (5), $n$-butyl (6), iso-propyl (7), sec-butyl (8), tert-butyl (9) orsellinates was evaluated using 2,2'-diphenyl-1-picrylhydrazyl (DPPH) method. Results showed that chain elongation of methyl (3) to $n$-butyl (6) causes a rise in the antioxidant activity. However, iso-propyl (7) and tert-butyl (9) were more active than the correspondent linear compounds, although sec-butyl (8) was less active among the chain ramified compounds. All the orsellinates were less active than lecanoric acid (1) and orsellinic acid (2). Orcinol (10) and resorcinol (11) were also determined for comparison with activities of orsellinates. Gallic acid (12) was used as control.
\end{abstract}

Key words Parmotrema tinctorum; antioxidant; orsellinate; 2,2' -diphenyl-1-picrylhydrazyl

Lichens produce phenolic compounds, such as depsides, depsidones, dibenzofuranes, usnic acids, depsones and others. Many of them are exclusive of lichens. ${ }^{1)}$ These substances, as well as their derivatives obtained by structural modification, have shown an ample variety of pharmacological activities: antibiotic, antimycobacterial, antiviral, antitumour, analgesic, antipyretic and enzyme inhibitory. ${ }^{2-5)} \mathrm{Al}-$ though these activities continue to be investigated, both in lichen extracts and with pure substances, a number of others have been attributed to the compounds produced by lichens, such as anti-human immunodeficiency virus (anti-HIV) ${ }^{6}$ ) and anti-herpes simplex virus 1 (anti-HSV-1). ${ }^{7}$ )

Numerous studies on the biological activities of phenols have indicated that these substances are also potent antioxidants and free radical scavengers. ${ }^{8)}$ Although the free radicals perform an important role in the organism, their cumulative effects can promote the initiation and/or progression of several diseases, including atherosclerosis, inflammation, cancer, cardiovascular diseases, ischaemia, aging and other degenerative diseases. ${ }^{9-11)}$

The antioxidants are of interest in the treatment of several cellular degenerations, and they inhibit or delay the oxidation process by blocking the initiation or propagation of oxidizing chain reactions. ${ }^{12)}$ They are also used to preserve food by retarding rancidity, discoloration, or deterioration due to autoxidation. ${ }^{13)}$ Due to the importance of antioxidants, many researches have been carried out with plants of several families and with simple phenolic substances, like those of the hydroxycinnamates group and the gallic acid derivatives. ${ }^{14-17)}$

Although the lichens are an important source of phenolic substances, studies of antioxidant activity with this group are more recent, and they have been performed mainly with extracts of some species. ${ }^{12,18-21)}$

We have investigated lichens from the "cerrado" of the Mato Grosso do Sul State, in Brazil, through the isolation, structural elucidation, structural modifications and evaluation of biological activities of phenolic substances. The lecanoric acid isolated from the lichen Parmotrema tinctorum, and the orsellinates obtained through reactions of this acid with alcohols were evaluated against Artemia salina and microorgan- isms. ${ }^{22-24)}$

In continuing our investigations, we are relating here the results of the antioxidant activity of the lecanoric acid (1), orsellinic acid (2) and the methyl (3), ethyl (4), $n$-propyl (5), n-butyl (6), iso-propyl (7), sec-butyl (8) and tert-butyl (9) orsellinates. With the aim of establishing a qualitative correlation structure-activity we have also included the antioxidant activity of orcinol (10), resorcinol (11) and gallic acid (12).

\section{Results and Discussion}

2,2'-Diphenyl-1-picrylhydrazyl (DPPH) Radical-Scavenging Activity Antioxidants are closely related to their biofunctionalities, such as the reduction of chronic diseases like DNA damage, mutagenesis, carcinogenesis and inhibition of pathogenic bacteria growth, which is often associated with the termination of free radical propagation in biological systems. ${ }^{25)}$ Thus, antioxidant capacity is widely used as a parameter for medicinal bioactive components.

In this study, free radical scavenging activities of lecanoric acid (1), orsellinic acid (2) and their derivatives 2,4-dihydroxy-6-methylbenzoates (3) to (9) (orsellinates), orcinol (10) resorcinol (11) and gallic acid (12) (Fig. 1) were determined using an in vitro test of DPPH.

The method is based on the reduction of methanolic DPPH solution in the presence of a hydrogen donating antioxidant, due to the formation of the non-radical form DPPH-H by the reaction. The reduction in DPPH radical was determined by the decrease in its absorbance at $517 \mathrm{~nm}$ induced by antioxidants, resulting in a color change from purple to yellow. Hence DPPH radical is usually used as a substrate to evaluate the antioxidative action of antioxidants.

Free radical-scavenging capacities of the corresponding compounds were measured by DPPH assay and the results are shown in Table 1. The phenolic compounds orcinol (10), and resorcinol (11) inhibited DPPH absorption with values up to $\mathrm{IC}_{50} 2.93 \pm 0.83$ and $1.84 \pm 1.01 \mathrm{~mm}$, respectively, while the lecanoric and orsellinic acids (1) and (2) inhibited with values up to $42.87 \pm 1.20$ and $5.01 \pm 0.66 \mathrm{~mm}$, respectively. For the derivatives 2,4-dihydroxy-6-methylbenzoates (orselli- 


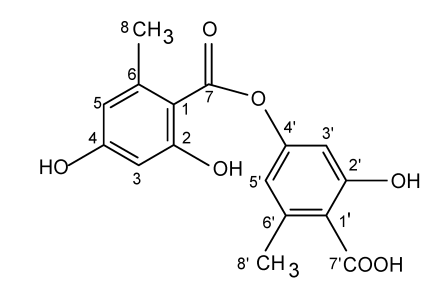

Lecanoric acid (1)

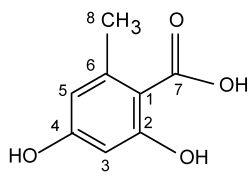

Orsellinic acid (2)

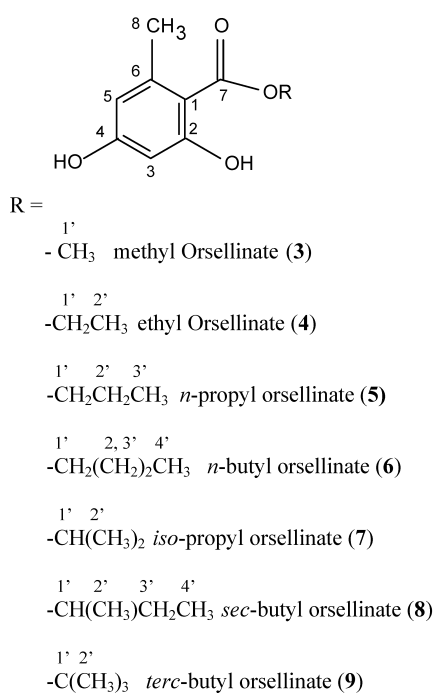

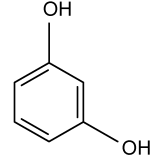

Resorcinol (11)

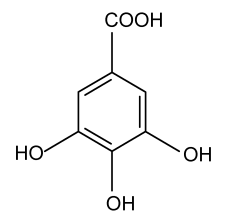

Gallic acid (12)

Fig. 1. Structures of the Substances Evaluated on DPPH

Table 1. Antioxidant Activity of Compounds (1)-(12) as Measured Using DPPH Free Radical in Methanol Solution

\begin{tabular}{lr}
\hline \multicolumn{1}{c}{ Substances } & $\mathrm{IC}_{50}$ value (mM) \\
\hline Lecanoric acid (1) & $42.87 \pm 1.20$ \\
Orsellinic acid (2) & $5.01 \pm 0.66$ \\
Methyl orsellinate (3) & $167.25 \pm 0.23$ \\
Ethyl orsellinate (4) & $120.53 \pm 0.18$ \\
n-Propyl orsellinate (5) & $87.24 \pm 0.32$ \\
n-Butyl orsellinate (6) & $55.65 \pm 0.47$ \\
iso-Propyl orsellinate (7) & $51.34 \pm 0.68$ \\
sec-Butyl orsellinate (8) & $74.70 \pm 0.15$ \\
tert-Butyl orsellinate (9) & $48.98 \pm 0.90$ \\
Orcinol (10) & $2.93 \pm 0.83$ \\
Resorcinol (11) & $1.84 \pm 1.01$ \\
Gallic acid (12) & $6.36 \times 10^{-3} \pm 0.68$ \\
\hline
\end{tabular}

nates) (3) to (9) the values were up to $\mathrm{IC}_{50} 48.98 \pm 0.90$ to $167.25 \pm 0.23 \mathrm{~mm}$. These values for the phenolic compounds can be considered as a full absorption inhibition of DPPH because, after completing the reaction, the final solution always has a yellowish color. ${ }^{26)}$

Radical-scavenging activity of phenolics depends, among other factors, on the number and position of hydroxyl $(-\mathrm{OH})$ group substituents in the molecules. ${ }^{27-29)}$ The presence of the carboxyl, alkyl or other groups affects the antioxidant activity of phenol compounds. The carboxyl group is an electron-withdrawing group, which does not benefit from radicalscavenging; however, in $\mathrm{pH}$ around 4.0 the ionization of the carboxyl group occurs, and the carboxlylate group becomes an electron-donating group which favours $\mathrm{H}$-atom-transferand electron-donating based on radical-scavenging. ${ }^{17,30)}$ The

alkyl group in the para-position is favourable for electron delocalization and stabilization of the phenoxyl radical. ${ }^{31)}$ The second hydroxyl group in the ortho- or para-position affects additional resonance stability. Moreover, the products of oxidation are ortho- and para-quinones. In the case of $m$-dihydroxybenzene the formation of quinone is not possible. The efficiency of ortho and para phenols is in part due to the stabilization of the aryloxyl radical by hydrogen bonding or by regeneration of other diphenols. ${ }^{32)}$

From the results, orsellinic acid (2) orcinol (10) and resorcinol (11) exhibited activity more intense than the lecanoric acid (1) and the orsellinates (3) to (9), but the resorcinol (11) was more active in scavenging than the orcinol (10) and orsellinic acid (2). This may be due to the influence of a methyl group present in the orcinol and orsellinic compounds and a carboxyl group present in the orsellinic acid. The $-\mathrm{CH}_{3}$ group linked at $m$-position relative to hydroxyl groups of the orcinol has no significant effect on stabilization of the radical by resonance. ${ }^{27)}$ Orsellinic acid (2) differs from orcinol (10) with respect to the carboxyl group in the ortho-position relative to one hydroxyl and one methyl group. The carboxyl is an electron-withdrawing group which does not benefit from radical-scavenging. However, the desprotonated carboxyl becomes an electron-donating group which favours H-atomtransfer- and electron-donation based radical-scavenging. ${ }^{17)}$ The establishment of hydrogen bonds between the oxygen of carbonyl and the hydrogen of hydroxyl group in ortho position also contribute to the lower activity of the orsellinic acid (2) relative to the orcinol $(\mathbf{1 0})$.

The presence of hydrogen bond was confirmed through the ${ }^{1} \mathrm{H}-\mathrm{NMR}$ spectra. The spectrum of orcinol (10) showed a signal at $\delta 8.08$ that was attributed to two $\mathrm{OH}$ phenolics. However the spectra of the orsellinic acid (2) and alkyl orsellinate (3) to (9) showed signals at $\delta 9.1$ and $\delta 11.6-12.0$ that were attributed to $\mathrm{OH}$ at $\mathrm{C}-4$ and $\mathrm{C}-2$, respectively. The hydrogen of phenolic hydroxyl at $\mathrm{C}-2$ is shifted far downfield due to the intermolecular hydrogen bond with the carbonyl group at ortho position. ${ }^{33)}$

The esterification of the carboxyl group of the orsellinic acid (2) produced a significant reduction in the radical-scavenging activity so, the alkyl orsellinates (3) to (9) showed values up to $\mathrm{IC}_{50} 48.98 \pm 0.90$ to $167.25 \pm 0.23 \mathrm{~mm}$.

The methyl (3), ethyl (4), $n$-propyl (5) and $n$-butyl (6) esters showed a rise in activity with the chain elongation. Compounds with ramified chains - iso-propyl (7) and tert-butyl (9) were more active than the $n$-propyl (5) and $n$-butyl (6) orsellinates. These results indicated that iso-propyl and tertbutyl groups favour the stabilization of the phenoxyl radical more that the corresponding linear chain. The sec-butyl orsellinate (8) was less active among the compounds with ramified chain than the $n$-butyl orsellinate (6). The ${ }^{1} \mathrm{H}$-NMR spectra of (3) to (9) showed a similar profile as the orsellinic acid with respect to the intermolecular hydrogen bond between $-\mathrm{OH}$ at $\mathrm{C}-2$ and the carbonyl group at ortho position.

Protocatechuyl alcohol, hydroxytyrosol and dihydrocaffeoyl alcohol and their methoxylated derivatives at meta position relative to the alkyl group showed an increased radicalscavenging capacity. According to Pinedo et al. ${ }^{34)}$ it is probable that as the alkyl chain connecting the phenolic ring increases, its electron-donating activity also increases, resulting in a well-stabilized phenoxy radical. 
Lu et al., ${ }^{16)}$ in studying the radical-scavenging activity of methyl, propyl, octyl and dodecyl gallates, have verified that the chain elongation causes a decrease in the activity. Based on these results they considered that the steric freedom is also important for the activity of antioxidant compounds. Methyl and propyl gallates, when compared with methyl (3) and $n$-propyl (5) orsellinates, are more active due to the presence of three hydroxyl groups in the gallates in positions that have not established a hydrogen bond with the carbonyl group of esters.

Noteworthy is the scavenging activity of free radicals (DPPH) of the orsellinates (3) to (6) which increases with the chain elongation and that of (7) and (9) which are more active than the corresponding linear chain.

Further studies on the structure-activity are required to elucidate the behaviour of phenol derivatives relative to radical-scavenging activity. According to Silva et al., ${ }^{35)}$ the molecular conformation could be one of the factors affecting their antiradical activity, which is intrinsically related to DPPH.

\section{Conclusions}

In conclusion, we have studied the antioxidant activity of orsellinates. Orcinol and resorcinol were also evaluated with the aim of comparing their activities on DPPH with those of orsellinic acid and the orsellinates. The orsellinates, particularly, differ from the orcinol and orsellinic acid only with respect to an ester group in the ortho-position to methyl and to one hydroxyl group. They presented a scavenging of free radical activity (DPPH) lower than that of the orcinol and orsellinic acid. These results may be related to the establishment of a hydrogen bond between the hydroxyl group at C-2 with the carbonyl group in the orsellinates. Our results indicated an increase in the antioxidant activity with the chain elongation of methyl (3) to butyl orsellinates (6). The compounds with ramified chains such as iso-propyl (7) and tertbutyl (9) were more active than the corresponding linear chain, $n$-propyl (5) $n$-butyl orsellinates (6), although the secbutyl (8) derivative was less active than $n$-butyl orsellinate (6). Our results have also indicated that the effects of substituents in the aromatic ring may cause different behaviour in the scavenging free radical activity.

\section{Experimental}

Section General Procedures Si-gel (Merck 230 - 400 mesh) was used for chromatography column. NMR spectra was recorded on a Bruker DPX 300 spectrometer and the mass spectra on a Shimadzu QP 5050 spectrometer using direct injection and electron impact at $70 \mathrm{eV}$. Melting points were determined on a Uniscience Melting Point apparatus.

Procedure for the Preparation of Derivatives Lecanoric acid (1) was isolated and purified from Parmotrema tinctorum (NYL.) Hale according to Ahmann and Mathey. ${ }^{36)}$ The preparation of the orsellinic acid (2) and orsellinates (3) to (9) was carried out through the reaction of lecanoric acid $\left(200 \mathrm{mg}\right.$ ) with $50 \mathrm{ml}$ of alcohol at $40^{\circ} \mathrm{C}$ in a steam bath. After completion of the reaction, the mixture was concentrated and the compounds were separated by chromatography on a silica column with chloroform and chloroform/acetone gradient. In all reactions orsellinic acid (2) and the corresponding esters 2,4-dihydroxy-6-methylbenzoates (orsellinates) (3) to (9) were obtained. The structures were confirmed through the analysis of ${ }^{1} \mathrm{H}$, ${ }^{13} \mathrm{C}$ and DEPT $135^{\circ}$ and EI-MS spectra.

Lecanoric Acid (1): ${ }^{1} \mathrm{H}-\mathrm{NMR}$ (DMSO- $\left.d_{6}\right) \delta: 10.48\left(1 \mathrm{H}, \mathrm{s}, \mathrm{ArOH}-2,2^{\prime}\right)$, $10.02\left(1 \mathrm{H}, \mathrm{s}, \mathrm{ArOH}-4,4^{\prime}\right), 6.59\left(2 \mathrm{H}, \mathrm{s}, \mathrm{ArH}-5,5^{\prime}\right), 6.21\left(2 \mathrm{H}, \mathrm{s}, \mathrm{ArH}-3,3^{\prime}\right)$, 2.35, $2.33\left(6 \mathrm{H}, \mathrm{s}, \mathrm{ArCH}_{3}-8,8^{\prime}\right) .{ }^{13} \mathrm{C}-\mathrm{NMR}$ (DMSO- $\left.d_{6}\right) \delta: 170.7\left(\mathrm{C}-7^{\prime}\right)$, 167.2 (C-7), 161.2 (C-4), 160.2 (C-2), 158.8 (C-2'), 152.3 (C-4'), 140.43 (C-6), $139.56\left(\mathrm{C}-6^{\prime}\right), 116.6\left(\mathrm{C}-1^{\prime}\right), 114.8\left(\mathrm{C}-5^{\prime}\right), 109.9(\mathrm{C}-5), 108.26$ (C-1),
$107.45\left({\mathrm{C}-3^{\prime}}^{\prime}\right), 100.5$ (C-3), $21.4\left(\mathrm{C}-8^{\prime}\right), 21.0(\mathrm{C}-8){ }^{37)}$

Orsellinic Acid (2): ${ }^{1} \mathrm{H}-\mathrm{NMR}$ (acetone- $\left.d_{6}\right) \delta$ : $11.8(1 \mathrm{H}, \mathrm{s}, \mathrm{ArOH}-2)$, 9.1(1H, s, ArOH-4), $6.27(1 \mathrm{H}, \mathrm{s}, \mathrm{ArH}-5), 6.22(1 \mathrm{H}, \mathrm{s}, \mathrm{ArH}-3), 2.5(3 \mathrm{H}, \mathrm{s}$, $\left.\mathrm{ArCH}_{3}-8\right) .{ }^{13} \mathrm{C}-\mathrm{NMR}$ (acetone- $\left.d_{6}\right) \delta: 174.2(\mathrm{C}-7), 167.0(\mathrm{C}-4), 163.2(\mathrm{C}-2)$, 144.9 (C-6), 112.0 (C-5), 105.1 (C-1), 101.4 (C-3), 24.2 (C-8). mp 196$197^{\circ} \mathrm{C} .^{37)}$

Methyl Orsellinate (3): ${ }^{1} \mathrm{H}-\mathrm{NMR}$ (acetone- $\left.d_{6}\right) \delta$ : $11.6(1 \mathrm{H}, \mathrm{s}, \mathrm{ArOH}-2)$, $9.1(1 \mathrm{H}, \mathrm{s}, \mathrm{ArOH}-4), 6.26$ (1H, s, ArH-5), $6.22(1 \mathrm{H}, \mathrm{s}, \mathrm{ArH}-3), 3.9$ (3H, s, $\left.-\mathrm{OCH}_{3}\right), 2.4\left(3 \mathrm{H}, \mathrm{s}, \mathrm{ArCH}_{3}-8\right) .{ }^{13} \mathrm{C}-\mathrm{NMR}$ (acetone- $\left.d_{6}\right) \delta: 172.7(\mathrm{C}-7), 166.0$ (C-4), 163.0 (C-2), 144.1 (C-6), 112.1 (C-5), 105.1 (C-1), 101.4 (C-3), 51.9 $\left(\mathrm{OCH}_{3}-1^{\prime}\right), 24.0(\mathrm{C}-8)$. EI-MS $m / z$ : $181 . \mathrm{mp} 143-144^{\circ} \mathrm{C}$.

Ethyl Orsellinate (4): ${ }^{1} \mathrm{H}-\mathrm{NMR}$ (acetone- $\left.d_{6}\right) \delta: 11.7(1 \mathrm{H}, \mathrm{s}, \mathrm{ArOH}-2), 9.1$ $(1 \mathrm{H}, \mathrm{s}, \mathrm{ArOH}-4), 6.27$ (1H, s, ArH-5), $6.22(1 \mathrm{H}, \mathrm{s}, \mathrm{ArH}-3), 4.4(2 \mathrm{H}, \mathrm{q}$, $\left.J=7.1 \mathrm{~Hz},-\mathrm{CH}_{2}-1^{\prime}\right), 2.5\left(3 \mathrm{H}, \mathrm{s}, \mathrm{ArCH}_{3}-8\right), 1.4\left(3 \mathrm{H}, \mathrm{t}, J=7.1 \mathrm{~Hz}, \mathrm{CH}_{3}-2^{\prime}\right)$. ${ }^{13} \mathrm{C}-\mathrm{NMR}$ (acetone- $d_{6}$ ) $\delta$ : $172.6(\mathrm{C}-7), 166.4(\mathrm{C}-4), 163.2(\mathrm{C}-2), 144.4(\mathrm{C}-$ 6), 112.1 (C-5), 105.4 (C-1), 101.6 (C-3), 61.9 (C-1'), 24.4 (C-8), 14.4 (C$\left.2^{\prime}\right)$. EI-MS $m / z$ : $196 . \mathrm{mp} 135-136^{\circ} \mathrm{C}$.

$n$-Propyl Orsellinate (5): ${ }^{1} \mathrm{H}-\mathrm{NMR}$ (acetone- $\left.d_{6}\right) \delta$ : $11.8(1 \mathrm{H}, \mathrm{s}, \mathrm{ArOH}-2)$, $9.2(1 \mathrm{H}, \mathrm{s}, \mathrm{ArOH}-4), 6.29(1 \mathrm{H}, \mathrm{s}, \mathrm{Ar}-5), 6.24(1 \mathrm{H}, \mathrm{s}, \mathrm{ArOH}-3), 4.3(2 \mathrm{H}, \mathrm{t}$ $\left.J=7.4 \mathrm{~Hz}, \mathrm{CH}_{2}-1^{\prime}\right), 2.5$ ( $\left.3 \mathrm{H}, \mathrm{s}, \mathrm{ArCH}_{3}-8\right), 1.8\left(2 \mathrm{H}, \mathrm{m}, \mathrm{CH}_{2}-2^{\prime}\right), 1.0(3 \mathrm{H}, \mathrm{t}$, $\left.J=7.4 \mathrm{~Hz}, \mathrm{CH}_{3}-3^{\prime}\right) .{ }^{13} \mathrm{C}-\mathrm{NMR}$ (acetone-d $) \delta: 172.5(\mathrm{C}-7), 166.3(\mathrm{C}-4)$, 163.0 (C-2), 112.1 (C-5), 105.2 (C-1), 101.5 (C-3), 67.4 (C-1'), 24.8 (C-8), $22.4\left(\mathrm{C}-2^{\prime}\right), 10.8\left(\mathrm{C}-3^{\prime}\right)$. EI-MS $m / z$ : $210 . \mathrm{mp} 131-132^{\circ} \mathrm{C}$

$n$-Butyl Orsellinate (6): ${ }^{1} \mathrm{H}-\mathrm{NMR}$ (acetone- $\left.d_{6}\right) \delta$ : $11.7(1 \mathrm{H}, \mathrm{s}, \mathrm{ArOH}-2)$, $9.1(1 \mathrm{H}, \mathrm{s}, \mathrm{ArOH}-4), 6.28(1 \mathrm{H}, \mathrm{s}, \mathrm{Ar}-5), 6.23(1 \mathrm{H}, \mathrm{s}, \mathrm{ArOH}-3), 4.3(2 \mathrm{H}, \mathrm{t}$, $\left.J=7.35 \mathrm{~Hz}, \mathrm{CH}_{2}-1^{\prime}\right), 2.5$ ( $\left.3 \mathrm{H}, \mathrm{s}, \mathrm{ArCH}_{3}-8\right), 1.8\left(2 \mathrm{H}, \mathrm{m}, \mathrm{CH}_{2}-2^{\prime}\right), 1.5(2 \mathrm{H}$, $\left.\mathrm{m}, \mathrm{CH}_{2}-3^{\prime}\right) 0.9\left(3 \mathrm{H}, \mathrm{t}, J=7.35 \mathrm{~Hz}, \mathrm{CH}_{3}-4^{\prime}\right) .{ }^{13} \mathrm{C}$-NMR (acetone- $\left.d_{6}\right) \delta: 172.5$ (C-7), 166.3 (C-4), 163.0 (C-2), 144.2 (C-6), 112.1 (C-5), 105.2 (C-1), 101.5

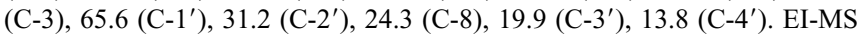
$m / z: 224 . \mathrm{mp} 94-95^{\circ} \mathrm{C}$.

iso-Propyl Orsellinate (7): ${ }^{1} \mathrm{H}-\mathrm{NMR}$ (acetone- $\left.d_{6}\right) \delta: 11.8(1 \mathrm{H}, \mathrm{s}, \mathrm{ArOH}-2)$, $9.2(1 \mathrm{H}, \mathrm{s}, \mathrm{ArOH}-4), 6.25(1 \mathrm{H}, \mathrm{s}, \mathrm{Ar}-5), 6.21(1 \mathrm{H}, \mathrm{s}, \mathrm{ArOH}-3), 5.2(1 \mathrm{H}, \mathrm{m}$, CH-1' $), 2.5\left(3 \mathrm{H}, \mathrm{s}, \mathrm{ArCH}_{3}-8\right), 1.4\left(6 \mathrm{H}, \mathrm{d}, \mathrm{CH}_{3}-2^{\prime}\right) .{ }^{13} \mathrm{C}-\mathrm{NMR}$ (acetone- $d_{6}$ ) $\delta$ : $172.1(\mathrm{C}-7), 166.4$ (C-4), 163.1 (C-2), 144.4 (C-6), 112.3 (C-5), 105.6 (C-1), $101.6(\mathrm{C}-3), 69.9\left({\mathrm{C}-1^{\prime}}^{\prime}\right), 24.5$ (C-8), 22.1 (C-2'). EI-MS m/z: 210. mp $117-118^{\circ} \mathrm{C}$

sec-Butyl Orsellinate (8): ${ }^{1} \mathrm{H}-\mathrm{NMR}$ (acetone- $\left.d_{6}\right) \delta: 11.8(1 \mathrm{H}, \mathrm{s}, \mathrm{ArOH}-2)$, $9.2(1 \mathrm{H}, \mathrm{s}, \mathrm{ArOH}-4), 6.28(1 \mathrm{H}, \mathrm{s}, \mathrm{Ar}-5), 6.24(1 \mathrm{H}, \mathrm{s}, \mathrm{ArOH}-3), 5.1(1 \mathrm{H}, \mathrm{m}$, CH-1'), 2.5 (3H, s, $\left.\mathrm{ArCH}_{3}-8\right), 1.7\left(2 \mathrm{H}, \mathrm{m}, \mathrm{CH}_{2}-3^{\prime}\right), 1.4(3 \mathrm{H}, \mathrm{d}, J=6.4 \mathrm{~Hz}$, $\left.\mathrm{CH}_{3}-2^{\prime}\right), 1.0\left(3 \mathrm{H}, \mathrm{t}, J=7.1 \mathrm{~Hz}, \mathrm{CH}_{3}-3^{\prime}\right) .{ }^{13} \mathrm{C}-\mathrm{NMR}$ (acetone- $\left.d_{6}\right) \delta: 171.6(\mathrm{C}-$ 7), 165.5 (C-4), 162.6 (C-2), 143.5 (C-6), 111.6 (C-5), 104.7 (C-1), 100.9

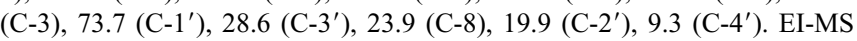
$m / z: 224 . \operatorname{mp~} 87-88^{\circ} \mathrm{C}$.

tert-Butyl Orsellinate (9): ${ }^{1} \mathrm{H}-\mathrm{NMR}$ (acetone- $\left.d_{6}\right) \delta: 11.8(1 \mathrm{H}, \mathrm{s}, \mathrm{ArOH}-2)$, $9.1(1 \mathrm{H}, \mathrm{s}, \mathrm{ArOH}-4), 6.24(1 \mathrm{H}, \mathrm{s}, \mathrm{Ar}-5), 6.21(1 \mathrm{H}, \mathrm{s}, \mathrm{ArOH}-3), 2.4(3 \mathrm{H}, \mathrm{s}$, $\left.\mathrm{ArCH}_{3}-8\right), 1.6\left(9 \mathrm{H}, \mathrm{s}, \mathrm{CH}_{3}-2^{\prime}\right) .{ }^{13} \mathrm{C}-\mathrm{NMR}$ (acetone- $\left.d_{6}\right) \delta: 172.2(\mathrm{C}-7), 166.4$ (C-4), 162.9 (C-2), 144.2 (C-6), 112.2 (C-5), 106.5 (C-1), 101.7 (C-3), 83.7 $\left(\mathrm{C}-1^{\prime}\right), 28.5\left(\mathrm{C}-2^{\prime}\right), 24.8(\mathrm{C}-8)$. EI-MS $m / z$ : $224 . \mathrm{mp} 157-158^{\circ} \mathrm{C}$.

Orcinol (10): ${ }^{1} \mathrm{H}-\mathrm{NMR}$ (acetone- $\left.d_{6}\right) \delta: 8.1(2 \mathrm{H}, \mathrm{s}, \mathrm{ArOH}), 6.15(2 \mathrm{H}$, $\mathrm{ArH}), 2.15\left(3 \mathrm{H}, \mathrm{ArCH}_{3}\right) .{ }^{13} \mathrm{C}-\mathrm{NMR}$ (acetone- $\left.d_{6}\right) \delta: 158.2(\mathrm{C}-3, \mathrm{C}-5), 139.7$ (C-1), 107.4 (C-2, C-6), 99.7 (C-4), 20.6 (C-7). mp 106-108 ${ }^{\circ} \mathrm{C}^{37)}$

Purification of Phenols The resorcinol used was obtained in analytical grade from Merck (Darmstadt, Germany) and orcinol from Sigma (St. Louis, MO, U.S.A.). The purity of each compound was checked through mp and NMR spectra.

Evaluation of Antioxidant Activity by Scavenging of DPPH Radical The antioxidant activity of the phenolic compounds, based on the scavenging activity of the stable 2,2'-diphenyl-1-picrylhydrazyl (DPPH) free radical, was determined by the method described by Blois ${ }^{38)}$ and Mokbel and Hashinaga. ${ }^{39)}$ The lecanoric acid, resorcinol, orcinol, orsellinic acid and the orsellinate (methyl, ethyl, $n$-propyl, $n$-butyl, iso-propyl, sec-butyl, tert-butyl) solutions $(1.0 \mathrm{ml})$ in methanol at different concentrations were added to a $2 \mathrm{ml} 0.004 \%(\mathrm{w} / \mathrm{v})$ solution of DPPH in methanol, previously prepared daily and protected from light. The reaction mixture was incubated at room temperature in the dark for $30 \mathrm{~min}$, and then the absorbance of the reactive mixture was recorded using spectrophotometer at $517 \mathrm{~nm}$. Inhibition of the $\mathrm{DPPH}$ free radical in percent $(I \%)$ was calculated in following way: $I \%=\left(A_{\text {blank }}-A_{\text {sample }} / A_{\text {blank }}\right) \times 100$; where $A_{\text {blank }}$ is the absorbance of the control reaction (containing all reagents except the test compound), and $A_{\text {sample }}$ is the absorbance of the test compound. Compound concentration providing $50 \%$ inhibition $\left(\mathrm{IC}_{50}\right)$ was calculated from the graph plotting inhibition percentage against solution concentration. Tests were carried out in triplicate. Six different concentrations of each phenolic compound studied have been assayed in order to check the linearity of response and to establish the antioxi- 
dant activity values in the adequate linear range. Methanol was tested against DPPH - radical and this resulted in null effect on the absorbance at $517 \mathrm{~nm}$. Gallic acid (12), a known antioxidant, was used as positive control.

Acknowledgements The authors wish to acknowledge financial support from FUNDECT-MS and CPq-PROPP-UFMS. T.I.B.L. appreciates the fellowship from Cientific Iniciation-PET, and R.G.C. thanks the CNPq for its grant to her.

\section{References}

1) Nash T. H. III, "Lichen Biology-Introduction," Cambridge University Press, Cambridge, 1996.

2) Oksanen I., Appl. Microbiol. Biotechnol., 73, 723-734 (2006).

3) Müller K., Appl. Microbiol. Biotechnol., 56, 9-16 (2001).

4) Huneck S., Naturwissenschaften, 86, 559-570 (1999).

5) Matsubara H., Kinoshita K., Koyama K., Yang Y., Takahashi K., Yoshimurta I., Yamamoto Y., Miura Y., Kinoshita Y., J. Hattori Bot Lab., 83, 179-185 (1997).

6) Neamati N., Hong H., Mazumer A., Wang S., Suner S., Nicklans M. C., Milne G. W. A., Proska B., Pommier Y., J. Med. Chem., 40, 942951 (1997).

7) Cohen P. A., Huson J. B., Towers G. H. N., Experientia, 52, 180-183 (1996).

8) Kähkönen M. P., Hopia A. I., Vuorela H. J., Ranha J., Pihlaja K., Kujala T. S., Heinonen M., J. Agric. Food Chem., 47, 3954-3962 (1999).

9) Halliwell B., Nutr. Rev., 55, 544-552 (1997).

10) Visioli F., Borsani L., Galli C., Cardiovasc. Res., 47, 419-425 (2000)

11) Noguchi N., Niki E., Free Radic. Biol. Med., 28, 1538-1546 (2000).

12) Behera B. C., Verma N., Sonone A., Makhija U., LWT-Food Sci. Technol., 39, 80-85 (2006).

13) Huang S. C., Yen G. C., Chang L. W., Yen W. J., Duh P. D., J. Agric. Food Chem., 51, 2380-2383 (2003).

14) Yen G. C., Duh P. D., Tsai H. C., Food Chem., 79, 307-313 (2002).

15) Gülçin I., Toxicology, 217, 213-280 (2006).

16) Lu Z., Nie G., Belton P. S., Tang H., Zhao B., Neurochem. Int., 48, $263-274$ (2006).

17) Ji H.-F., Zhang H.-Y., Shen L., Bioorg. Med. Chem. Lett., 16, 3395 4098 (2006).

18) Jayaprakasha G. K., Rao L. J., Z. Naturforsch., 55c, 1018-1022 (2000).
19) Gülçin I., Oktay M., Küfrevioglu Ö. I., Aslan A., J. Ethnopharmacol., 79, 325-329 (2002).

20) Odabasoglu F., Aslan A., Cakir A., Suleyman H., Karagoz Y., Bayer Y., Halice M., Fitoterapia, 76, 216-219 (2005).

21) Gulluce M., Aslan A., Sokmem M., Sahin F., Adiguzel A., Agar G., Sokmen A., Phytomedicine, 13, 515-521 (2006).

22) Gomes A. T., Honda N. K., Roese F. M., Muzzi R. M., Marques M. R. Rev. Bras. Farmacogn., 12, 74-75 (2002).

23) Gomes A. T., Smania Júnior A., Sediel C., Smania E. F. A., Honda N. K., Roese F. M., Muzzi R. M., Braz. J. Microbiol., 34, 194-196 (2003).

24) Gomes A. T., Honda N. K., Roese F. M., Muzzi R. M., Sauer L., Z. Naturforsch., 61c, 653-657 (2006).

25) Zhu Q. Y., Hackman R. M., Ensunsa J. L., Holt R. R., Keen C. L., J. Agric. Food Chem., 50, 6929-6934 (2002).

26) Miliauskas G., Venskutonis P. R., van Beek T. A., Food Chem., 85, 231-237 (2004)

27) Cai Yi-Z., Sun M., Xing J., Luo Q., Corke H., Life Sci., 78, 2872 2888 (2006).

28) Rice-Evans C., Miller N. J., Paganga G., Free Radic. Biol. Med., 20, 933-956 (1996)

29) Thavasi V., Leong L. P., Bettens R. P. A., J. Phys. Chem. A, 110, 4918-4923 (2006).

30) Hansch C., Leo A., Taff R. W., Chem. Rev., 91, 165-195 (1991).

31) Litwinienko G., Kasprzycka-Guttman T., Jamanek K., Termochim. Acta, 331, 79-86 (1999).

32) Brand-Williams W., Cuvelier M. E., Berset C., LWT-Food Sci. Technol., 28, 25-30 (1995).

33) Silverstein R. M., Bassler G. C., Morril T. C., "Spectrometric Identification of Organic Compounds," 5th ed., Wiley, New York, 1991.

34) Pinedo A. T., Peñalver P., Morales J. C., Food Chem., 103, 55-61 (2007).

35) Silva F. A. M., Boges F., Guimarães C., Lima J. L. F. C., Matos C., Reis S., J. Agric. Food Chem., 48, 2122-2126 (2000)

36) Ahmann G. B., Mathey A., Bryologyst, 70, 93-97 (1967).

37) Huneck S., Yoshimura L., "Identification of Lichen Substances," Springer, Berlin, 1996.

38) Blois M. S., Nature (London), 181, 1199-1200 (1958).

39) Mokbel M. S., Hashinaga F., Food Chem., 94, 529-534 (1996). 